\title{
Comparative Studies on Mineral and Scavenging Ability of Edible and Some Underexploited Wild Beans in Nigeria
}

\author{
0. A. Awoyinka' ${ }^{\text {, A. Ileola }}{ }^{2}$, C. N. Imeoria ${ }^{3}$, M. F. Asaolu ${ }^{2}$ \\ ${ }^{1}$ Department of Medical Biochemistry, College of Medicne, Ekiti State University, Ado Ekiti, Nigeria \\ ${ }^{2}$ Department of Biochemistry, Ekiti State University, Ado Ekiti, Nigeria \\ ${ }^{3}$ Department of Science Laboratory Technology, Ekiti State University, Ado Ekiti, Nigeria \\ Email: olayinka.awoyinka@eksu.edu.ng
}

Received 6 January 2016; accepted 22 January 2016; published 27 January 2016

Copyright (C) 2016 by authors and OALib.

This work is licensed under the Creative Commons Attribution International License (CC BY). http://creativecommons.org/licenses/by/4.0/

(c) (7) Open Access

\section{Abstract}

This work was set out to assay for some minerals essential for healthy state and biochemical indices that underlined degenerative diseases in some edible bean cultivar and nearly extinct local wild bean. Against this backdrop, ash composition was determined before $\mathrm{Na}^{+}, \mathrm{K}^{+}, \mathrm{Ca}^{2+}, \mathrm{Mg}^{2+}, \mathrm{Zn}^{2+}$, $\mathrm{Fe}^{2+}, \mathrm{Pb}^{2+}$ and $\mathrm{Cd}$ were determined by Flame Photometer and Atomic Absorption Spectroscopy (AAS) respectively. 2,2-diphenyl-1-picrylhydrazyl (DPPH), Vitamin E and Vitamin C were also assayed to determine the scavenging ability of the bean samples. The proximate ash composition result of unprocessed and malted edible bean IT99K-573-2-1 had the highest ash content value of $6.90 \pm 0.01$ and $6.92 \pm 0.01$ respectively. In the bean samples $\mathrm{Pb}^{2+}$ and $\mathrm{Cd}^{2+}$ were not detected. The empirical mineral composition varies across both the wild and edible bean without significant difference $(P \leq 0.05)$ except IT07K-243-1-10 that had $\mathrm{Ca}^{2+}$ to be significantly higher than other bean samples. $\mathrm{K}^{+}$was found to be significantly higher in Feregede and IT07K-243-1-10 compared to other bean samples. Changes in the radical scavenging ability of the various sample in this study after malting, showed a slight reduction in DPPH content except for the edible beans-IT04K-333-2 and IT845-2246-4. Well, there was slight reduction of Vitamin E only in Otili, Mucuna and IT99K-573-1-1. Compared to others only Otili and IT845-2246-4 had slight reduction in Vitamin C after malting.

\section{Keywords}

Beans, Minerals, 2,2-Diphenyl-1-Picrylhydrazyl (DPPH), Vitamin E, Vitamin C

\section{Subject Areas: Biochemistry}

How to cite this paper: Awoyinka, O.A., Ileola, A., Imeoria, C.N. and Asaolu, M.F. (2016) Comparative Studies on Mineral and Scavenging Ability of Edible and Some Underexploited Wild Beans in Nigeria. Open Access Library Journal, 3: e2318. http://dx.doi.org/10.4236/oalib.1102318 


\section{Introduction}

Bean seeds are important staple foods, particularly in developing countries, due to their relatively very low cost, long conservation time, and high nutritional value [1]-[3]. They are second only to grains in supplying calories and protein to the world's population. They belong to an extremely large category of vegetables, containing more than thirteen thousand species [4] [5]. Most of the species are nearly extinct due to their under-exploitation for human use. Despite their small size, beans pack a surprisingly rich and varied array of substances that are vital for good health. Their nutritional contents contribute to many health benefits as well as some factors that can reduce the bioavailability of nutrients to human beings [6] [7]. Much interest has been generated in examining some of these compounds with respect to chronic disease prevention such as diabetes and cancer [8]-[11].

Dry beans are an excellent source of the water-soluble vitamins; thiamine and folic acid and a good source of riboflavin and vitamin B6. They are rich source of iron, which makes them ideal for vegetarians who do not get an animal source of iron [12]-[14]. Most of the research on dry beans has been related to varietal selection. The criteria for selection have always been resistance to diseases or yields but nutritional quality. For example, Balogun and Fetuga [15] evaluated 16 wild underexploited legume seeds (family: Mimosoideae, Caesalpinoideae, and Papilionoideae) for their proximate composition and mineral content. All the leguminous seeds studied were rich in minerals like calcium, phosphorus, and potassium, with low levels of sodium. However, Ajayi et al., [16] investigated the composition, physicochemical properties, oil, and fatty acid content of 3 underutilized legumes from Nigeria, B. eurycoma, T. indica, and Mucuna flagellipes. Fasoyiro et al., [17] undertook a comparative study on the proximate, mineral, and antinutritional qualities of some underutilized grain legumes of southwestern (from Oyo and Ondo States) Nigeria. The legumes included African yam bean (2 types of Sphenotylis stenocarpa), bambara groundnut (Vigna subterranean), pigeon pea (Cajanus cajan), and lima bean (Phaseolus luunatus). However, Nwosu [18] assessed the nutritional composition of Sphenotylis stenocarpa an underutilized legumes, using malting treatment.

This present study on the mineral composition and scavenging ability of dry beans (unprocessed) and malted beans (processed) would therefore be of great interest. The knowledge provided would help to orient the work of investigators involved in varietal selection and also reduce or eliminate anti-nutritional factors to make edible and non-edible legume seeds more acceptable as an inexpensive source of protein.

\section{Materials and Method}

\subsection{Collection of Cultivar}

Dry, wild bean-Sphenostyles stenocarpa (Otili), Cajanus cajan (Feregede), Phaseolus lunatus (Pakala), were sourced from the bush of Ado Ekiti environ while the wild type-Mucuna cochindunum (Mucuna), and edible type bean-Phaseolus vulgaris tagged, IT845-2246-4 were brought from International Institute of Tropical Agriculture (IITA), Ibadan Nigeria. They were collected whole, dry and naked (i.e. without pods), with divers colors (off white, gold, navy blue, black and brown respectively). Authentication (Table 1) was carried out at the herbarium of the Plant Science Department, Ekiti State University Ado Ekiti, Nigeria.

\subsection{Proximate Ash Composition}

$2 \mathrm{~g}$ of the sample is weighed into a pre-heated crucible. The crucible is placed into muffle furnace at $400^{\circ} \mathrm{C}$ $600^{\circ} \mathrm{C}$ for 4 hrs until whitish-grey ash is obtained. The crucible is then placed in the desiccator and weighed:

$$
\% \text { Ash }=\frac{\text { wt. of crucible }+ \text { ash }- \text { wt. of crucible }}{\text { wt. of sample }} .
$$

\subsection{Analysis of Minerals}

Flame Photometer was used for analysis of $\mathrm{Na}$ and $\mathrm{K}$ while Atomic Absorption Spectroscopy was used for analysis of $\mathrm{Cl}, \mathrm{Fe}, \mathrm{Pb}, \mathrm{Zn}, \mathrm{Mg}$ and $\mathrm{Ca}$.

\subsection{Determination of Vitamin $\mathrm{E}$}

The method of Pearson as modified by Maciej and Krzysztof [19] was used $1.0 \mathrm{~g}$ of bean sample with $10 \mathrm{ml}$ of 
Table 1. Identification of beans used in this study and their identification.

\begin{tabular}{ccc}
\hline Samples & Local/cultivar name & Botanical name \\
\hline A & Otili & Sphenostyles stenocarpa \\
B & Feregede & Cajanus cajan \\
C & Pakala & Phaseolus lunatus \\
D & Mucuna & Mucuna cochindunum \\
E & IT99K-573-2-1 & Phaseolus vulgaris \\
F & IT99K-573-1-1 & Phaseolus vulgaris \\
G & IT97K-499-35 & Phaseolus vulgaris \\
H & IT07K-243-1-10 & Phaseolus vulgaris \\
I & IT04K-333-2 & Phaseolus vulgaris \\
J & IT845-2246-4 & Phaseolus vulgaris \\
\hline
\end{tabular}

absolute alcohol and $20 \mathrm{ml}$ of $1 \mathrm{M}$ alcoholic sulphuric acid was reflux for 45 mins. After cooling, $50 \mathrm{ml}$ of water was added before extraction of the unsaponifiable matter with $5 \times 30 \mathrm{ml}$ diethyl ether and dry over anhydrous sodium sulphate. The residue re-dissolved in $10 \mathrm{ml}$ absolute alcohol before taking absorbance at $470 \mathrm{~nm}$ against blank containing absolute alcohol.

$$
\text { Concentration of sample }(\mathrm{mg} / \mathrm{ml})=\frac{\text { Abs. of sample } \times \text { concentration of standard }}{\text { Abs. of standard }}
$$

\subsection{Determination of Vitamin C}

The vitamin C content was determined by Benderitter et al., [20] using the ascorbic acid as the reference compound. $200 \mu \mathrm{l}$ of the extract was pipetted and mixed with $300 \mu \mathrm{l}$ of $13.3 \%$ of TCA (Tri-chloroacetic acid) and 75 $\mu \mathrm{l}$ of DNPH (Di-nitrophenylhydrazine). The mixture was incubated at $37^{\circ} \mathrm{C}$ for $3 \mathrm{hrs}$ and $500 \mu \mathrm{l}$ of $65 \% \mathrm{H}_{2} \mathrm{SO}_{4}$ was added. The absorbance was read at $520 \mathrm{~nm}$.

$$
\text { Vit. C } \mathrm{mg} / \mathrm{ml}=\frac{\text { absorbance of sample read on spectrophotometer }}{\text { Slope of the standard }(0.888)}
$$

\subsection{DPPH Assay}

The method described by Garcia et al., [21] was modified, 500 microlitres of prepared samples were respectively mixed with 500 microliters of methanolic solution containing $0.3 \mathrm{mmol} \cdot \mathrm{L}^{-1} \mathrm{DPPH}$ radicals. The mixture was shaken vigorously and left to stand for $30 \mathrm{~min}$ in the dark, and the absorbance was then measured at $516 \mathrm{~nm}$ against blank (methanol). The percentage scavenging effect was calculated according to the equation:

$$
\% \text { DPPH Scavenged }=\frac{\text { A reference }- \text { A sample }}{\text { A reference }} \times 100
$$

\section{Results and Discussion}

The consumption of beans has been associated to several health benefits like reduction of cholesterol level [22] and coronary heart diseases [23] [24], favorable effects against cancer [9], decrease of diabetes and obesity [25], high antioxidant capacity [26], antimutagenic [27] [28], and antiproliferative effects [29] [30] because they are good source of protein, essential vitamins and minerals, soluble-fiber starch, phytochemicals, and it is a low fat food [26]. The quality of bean seed is determined by the protein content, amino acid composition, digestibility, presence of anti-nutritional factors and mineral content [25] [31].

This study involves several analyses that comparatively studied the mineral content and scavenging ability of some wild and edible bean in relation to healthy living in humans. Ash content which represents the inorganic component (minerals) of the sample after all moisture and organic material has been removed, as well as the degree of purity of the beans was carried out on unprocessed and malted bean samples (Table 2). The result 
Table 2. Ash content of unprocessed bean sample and malted bean sample.

\begin{tabular}{cccc}
\hline Samples & Local name & Ash content for dry bean & Ash content for malted bean sample \\
\hline A & Otili & $4.20 \pm 0.13$ & $4.47 \pm 0.01$ \\
B & Feregede & $3.90 \pm 0.02$ & $43.35 \pm 0.02$ \\
C & Pakala & $5.10 \pm 0.15$ & $5.60 \pm 0.08$ \\
D & Mucuna & $3.42 \pm 0.02$ & $3.91 \pm 0.05$ \\
E & IT99K-573-2-1 & $6.91 \pm 0.01$ & $6.92 \pm 0.01$ \\
F & IT99K-573-1-1 & $5.68 \pm 0.01$ & $5.94 \pm 0.01$ \\
G & IT97K-499-35 & $3.46 \pm 0.01$ & $3.18 \pm 0.01$ \\
\hline
\end{tabular}

showed that edible bean IT99K-573-2-1 had the highest ash content value of $6.90 \pm 0.01$ in normal sample and $6.92 \pm 0.01$ in malted samples, subsequently followed by edible bean IT99K-573-1-1 with a value of $5.68 \pm 0.01$ in ordinary samples and $5.94 \pm 0.01$ in malted samples. Edible bean IT04K-333-2 had the lowest ash content with the value of $3.14 \pm 0.01$ in typical bean sample and $3.98 \pm 0.01$ in malted bean sample, followed by wild type bean mucuna with the value of $3.42 \pm 0.02$ in common bean sample and $3.91 \pm 0.51$ in malted samples. The relatively higher ash content of edible bean IT99K-573-2-1 (6.90 \pm 0.01$)$ generally indicates higher concentration of minerals than the other varieties. Significant difference $(\mathrm{p}<0.05)$ was observed between the malted and dried ash content for each samples implying that malting increases mineral content of the beans.

In all, eight metals were analysed out of which six were essential though in various amount i.e. micro and macro element $\left(\mathrm{Na}^{+}, \mathrm{Ca}^{2+}, \mathrm{K}^{+}, \mathrm{Mg}^{2+}, \mathrm{Zn}^{2+}\right.$ and $\left.\mathrm{Fe}^{2+}\right)$ while the rest two which were heavy metals $(\mathrm{Cd}$ and $\mathrm{Pb})$ were equally analysed. From the result (Table 3), Edible bean-IT07K-243-1-10 had the highest sodium content of 12.40 while wild bean-Otili had the least $\mathrm{Na}^{2+}$ content of 10.60 but generally, virtually all the samples have a range of $10.0-12.40 \mathrm{ppm}$. Sodium helps our body retaining the body's water and $\mathrm{pH}$. It enables cell to draw in nutrients [32]. Winham et al., [24] reported the association of high sodium content with hypertension. Higher sodium intake leads to the retention of more water including water in the blood vessels. This raises the blood pressure, if it raises the blood pressure too high, this can cause health problems such as hypertension.

Edible bean-IT07K-243-1-10 has the highest calcium $\left(\mathrm{Ca}^{2+}\right)$ content of 79.10 with a wide difference from Edible bean-IT04K-333-2 that has higher $\mathrm{Ca}^{2+}$ as $29.00 \mathrm{ppm}$ followed by wild bean-Pakala and Mucuna at 27.70 and 27.00 ppm respectively. Edible bean-IT97K-499-35 has the least $\mathrm{Ca}^{2+}$ content of $10.80 \mathrm{ppm}$. Edible bean IT99K-573-1-1 and IT845-2246-4 share equal amount of $\mathrm{Ca}^{2+}$ as 19.30. Edible bean-IT99K-573-2-1 has $23.70 \mathrm{ppm}$ of $\mathrm{Ca}^{2+}$ while wild bean-Mucuna and Otili has almost equal amount of $\mathrm{Ca}^{2+}$ as 11.90 and 11.40 respectively. Calcium deficiency has been epidemiologically linked to several chronic diseases, including osteoporosis, hypertension, and colon cancer [7].

Edible bean-IT07K-243-1-10 has highest amount of $\mathrm{K}^{+}$as $163 \mathrm{ppm}$ followed by samples B and I that share equal amount at $162.00 \mathrm{ppm}$. At concentration 147.00 wild bean-pakala took the fourth position while wild bean-Mucuna is fifth concentrated at 122.00 ppm, Edible bean-IT99K-573-1-1 has 118.00 ppm while Edible bean-IT99K-573-2-1 is 5 units above a hundred. Three samples have their concentrations less than a hundred as wild bean-Otili has 82.70 ppm, Edible bean-IT845-2246-4 has penultimate least at 79.80 ppm while Edible bean-IT97K-499-35 among others has least quantity of $\mathrm{Ca}^{2+}$ as $66.30 \mathrm{ppm}$. Potassium is nutritionally important in the maintenance of cellular water balance, $\mathrm{pH}$ regulation in the body and it is also associated with protein and carbohydrate metabolism [33]. A diet rich in potassium seems to lower blood pressure, getting enough potassium from diet may benefit bones.

The metals Cadmium and Lead could not even be traced in any amount for any of the samples. Lead and cadmium are non-essential metals as they are toxic, even in trace [34]. They are best known for their toxicological properties. $\mathrm{Pb}$ and $\mathrm{Cd}$ can be accumulated in biological systems, becoming potential contaminants along the alimentary chain. This implies that the Bean samples are completely free from heavy metals that can harm the living system.

All the samples has presence of $\mathrm{Mg}^{2+}$ at a close range with Edible bean-IT04K-333-2 having the greatest amount as $6.02 \mathrm{ppm}$ while wild bean-Otili has $4.86 \mathrm{ppm}$ as the least and the penultimate least is Edible beanIT97K-499-35 at concentration $4.99 \mathrm{ppm}$. The rest samples generally have some decimals above $5 \mathrm{ppm}$ for presence of $\mathrm{Mg}^{2+}$. 
Table 3. Result of some selected macro and micro element present in the unprocessed bean samples.

\begin{tabular}{|c|c|c|c|c|c|c|c|c|}
\hline Sample & $\mathrm{Na}^{+}(\mathbf{p p m})$ & $\mathrm{Ca}^{2+}(\mathrm{ppm})$ & $\mathrm{K}^{+}(\mathbf{p p m})$ & Cd (ppm) & $\mathrm{Mg}^{2+}(\mathrm{ppm})$ & $\mathrm{Zn}^{2+}(\mathbf{p p m})$ & $\mathrm{Fe}^{2+}(\mathrm{ppm})$ & $\begin{array}{c}\mathbf{P b}^{2+} \\
(\mathbf{p p m})\end{array}$ \\
\hline A & $10.60 \pm 0.216025$ & $11.40 \pm 0.374166$ & $82.70 \pm 0.478121$ & ND & $4.86 \pm 0.369143$ & $0.59 \pm 0.220454$ & $1.96 \pm 0.418171$ & ND \\
\hline B & $11.71 \pm 0.597571$ & $27.00 \pm 0.828654$ & $162.00 \pm 2.581989$ & ND & $5.30 \pm 0.297714$ & $1.27 \pm 0.347659$ & $2.20 \pm 0.258199$ & ND \\
\hline $\mathrm{C}$ & $11.49 \pm 0.275802$ & $27.70 \pm 0.593015$ & $147.00 \pm 4.546061$ & ND & $5.06 \pm 0.229202$ & $1.07 \pm 0.217409$ & $2.81 \pm 0.258521$ & ND \\
\hline $\mathrm{D}$ & $12.04 \pm 0.240555$ & $11.90 \pm 0.304453$ & $122.00 \pm 2.94392$ & ND & $5.41 \pm 0.424343$ & $1.32 \pm 0.178582$ & $2.96 \pm 0.479826$ & ND \\
\hline $\mathrm{E}$ & $11.99 \pm 0.564092$ & $23.70 \pm 0.227303$ & $105.00 \pm 4.082483$ & ND & $5.12 \pm 0.09798$ & $1.13 \pm 0.106145$ & $2.39 \pm 0.298273$ & ND \\
\hline $\mathrm{F}$ & $11.26 \pm 0.31496$ & $19.30 \pm 0.571548$ & $118.00 \pm 2.94392$ & ND & $5.40 \pm 0.322542$ & $1.31 \pm 0.34938$ & $2.60 \pm 0.279523$ & ND \\
\hline G & $11.44 \pm 0.455961$ & $10.80 \pm 0.209921$ & $66.30 \pm 0.50405$ & ND & $4.99 \pm 0.008165$ & $0.74 \pm 0.057155$ & $1.59 \pm 0.274712$ & ND \\
\hline $\mathrm{H}$ & $12.40 \pm 0.374166$ & $79.10 \pm 0.374166$ & $163.00 \pm 6.377042$ & ND & $5.26 \pm 0.279046$ & $1.24 \pm 0.163299$ & $2.87 \pm 0.31791$ & ND \\
\hline I & $11.93 \pm 0.248864$ & $29.00 \pm 0.227303$ & $162.00 \pm 2.160247$ & ND & $6.02 \pm 0.188326$ & $1.87 \pm 0.106145$ & $3.32 \pm 0.328634$ & ND \\
\hline $\mathrm{J}$ & $11.94 \pm 0.266521$ & $19.30 \pm 0.571548$ & $79.80 \pm 0.430581$ & ND & $5.08 \pm 0.058878$ & $1.06 \pm 0.208167$ & $2.08 \pm 0.379825$ & ND \\
\hline
\end{tabular}

Legumes are known as zinc accumulators [17] [35]. Generally, all the samples have the trace amount of $\mathrm{Zn}^{2+}$ because $\mathrm{Zn}^{2+}$ is a trace element. Edible bean-IT04K-333-2 has the greatest amount as $1.87 \mathrm{ppm}$ while wild bean —otili has the least amount as $0.59 \mathrm{ppm}$. The penultimate least quantified is found in Edible beanIT97K-499-35 as $0.74 \mathrm{ppm}$. The rest of the samples apart from the highest have some decimals above $1.00 \mathrm{ppm}$ $\mathrm{Zn}$ has been recognized as a co-factor of the superoxide dismutase enzyme, which is involved in protection against oxidative processes. The main symptoms of Zn deficiency include pregnancy complications, low birth weight, maternal and infant mortality and reduction of growth in infancy and childhood [36].

$\mathrm{Fe}^{2+}$ is found in all the bean samples in a trace amount. The sample with highest amount of $\mathrm{Fe}^{2+}$ is Edible bean-IT04K-333-2 as $3.32 \mathrm{ppm}$. The least amount of $\mathrm{Fe}^{2+}$ is found in Edible bean-IT97K-499-35 as 1.59 ppm while the penultimate least in $\mathrm{Fe}^{2+}$ is wild bean-Otili as $1.96 \mathrm{ppm}$. However, wild bean-mucuna is greater at $2.96 \mathrm{ppm}$ followed by Edible bean-IT07K-243-1-10 at $2.87 \mathrm{ppm}$ and wild bean-pakala at $2.81 \mathrm{ppm}$. The rest samples were few decimals above $2.0 \mathrm{ppm}$. Iron deficiency is the common nutrition disorder worldwide and affects a large proportion of women and children in developing countries. Indeed, an estimated 3.5 to 5 billion people are Fe deficient in the world [37] [38].

Further study to assess the changes in the radical scavenging ability of the various sample in this study before and after malting (Table $4 \&$ Table 5) showed that all the bean species exhibited antioxidant efficacy assessed by DPPH assay. DPPH content were lower in all bean samples after malting except in edible bean-IT04K333-2 and IT845-2246-4. Thus, indicating malting decreases DPPH content. It is shown that wild bean species consist of good antioxidant activity as compared to edible bean species.

Wild type bean - mucuna had the highest Vitamin E content in it with a value of $2.6791 \pm 0.0002$ in the dried bean, and $2.2371 \pm 0.000294$ in the malted sample while edible bean-IT07K-243-1-10 had the lowest vitamin E content with the value of $0.2578 \pm 0.001$ and $0.3101 \pm 0.000574$ in dry and malted bean respectively. Vitamin $\mathrm{E}$ is the most powerful natural antioxidant. It is involved in removal of free radicals and prevents their peroxidative effects on unsaturated lipids of membranes and thus helps maintain the integrity of cell membrane and reducing the risk of atherosclerosis [39] [40]. Vitamin E also protects red blood cells from hemolysis by preventing peroxidation. Vit E ( $\alpha$-tocopherol) reacts with the lipid peroxide radicals formed by peroxidation of polyunsaturated fatty acids before they can establish a chain reaction, acting as free radical trapping antioxidant [41]. The tocopheroxy-free radical product, formed in the process, is relatively unreactive and ultimately forms non-radical compounds. Usually the tocopheroxyl radical is reduced back to $\alpha$-tocopherol again by reaction with vitamin C from plasma or reduced glutathione (G-SH).

Vitamin C content was highest in Otili and brown edible bean-IT845-2246-4 with the value of $6.83 \pm 0.508$ and $4.22 \pm 0.046$ in dry samples and $4.90 \pm 0.228619$ and $3.08 \pm 0.32$. Thus dried pulverised Otili has more radical scavenging ability than other bean in this study. The fact that vitamin $C$ is very sensitive to reversible oxidation, Ascorbic acid to Dehydroascorbic acid, suggests that it may be involved in cellular oxidation reduction reactions, perhaps serving as hydrogen transport agent. Ascorbic acid is required for functional activities of fibroblasts, and osteoblasts, and consequently for formation of MPS of connective tissues, osteoid tissues, dentine and intercellular cement substance of capillaries [42]. 
Table 4. Table showing DPPH, Vitamin E and Vitamin C content of dry pulverized samples.

\begin{tabular}{cccc}
\hline Samples & DPPH & Vitamin E & Vitamin C \\
\hline A & $56.04 \pm 2.15$ & $0.9850 \pm 0.001$ & $6.83 \pm 0.508$ \\
B & $77.05 \pm 0.35$ & $0.3148 \pm 0.001$ & $3.85 \pm 0.338$ \\
C & $17.98 \pm 1.43$ & $1.4199 \pm 0.001$ & $2.09 \pm 0.374$ \\
D & $23.43 \pm 1.61$ & $2.6791 \pm 0.0002$ & $8.22 \pm 0.184$ \\
E & $63.03 \pm 0.33$ & $1.5900 \pm 0.001$ & $3.74 \pm 0.275$ \\
F & $69.52 \pm 0.08$ & $1.4787 \pm 0.003$ & $3.09 \pm 0.041$ \\
G & $72.15 \pm 0.09$ & $0.5486 \pm 0.001$ & $3.33 \pm 0.012$ \\
H & $64.89 \pm 0.60$ & $0.2578 \pm 0.001$ & $3.84 \pm 0.186$ \\
I & $64.87 \pm 0.05$ & $0.5040 \pm 0.001$ & $2.99 \pm 0.046$ \\
J & $62.59 \pm 0.33$ & $0.2942 \pm 0.001$ & $4.22 \pm 0.045$ \\
\hline
\end{tabular}

Table 5. Table showing DPPH, Vitamin E and Vitamin C of malted pulverized sample.

\begin{tabular}{|c|c|c|c|}
\hline Sample & DPPH & Vitamin E & Vitamin C \\
\hline A & $53.18 \pm 0.76$ & $0.0302 \pm 0.000648$ & $4.90 \pm 0.228619$ \\
\hline B & $58.04 \pm 0.25$ & $0.4452 \pm 0.000748$ & $9.84 \pm 0.465689$ \\
\hline $\mathrm{C}$ & $15.85 \pm 0.35$ & $0.2035 \pm 0.000206$ & $14.99 \pm 0.009574$ \\
\hline $\mathrm{D}$ & $19.28 \pm 1.06$ & $2.2371 \pm 0.000294$ & $11.49 \pm 0.273785$ \\
\hline $\mathrm{E}$ & $63.54 \pm 0.18$ & $1.9271 \pm 0.000572$ & $6.88 \pm 0.423507$ \\
\hline $\mathrm{F}$ & $41.66 \pm 0.63$ & $0.9333 \pm 0.00045$ & $21.63 \pm 0.183734$ \\
\hline G & $63.14 \pm 1.35$ & $0.8236 \pm 0.00042$ & $13.57 \pm 0.977493$ \\
\hline $\mathrm{H}$ & $54.34 \pm 0.71$ & $0.3101 \pm 0.000574$ & $5.12 \pm 0.222809$ \\
\hline I & $76.00 \pm 0.38$ & $0.5788 \pm 0.000492$ & $7.65 \pm 0.183757$ \\
\hline $\mathrm{J}$ & $72.50 \pm 0.86$ & $0.8236 \pm 0.00042$ & $3.08 \pm 0.323213$ \\
\hline
\end{tabular}

\section{Conclusion}

Arising from the comparative analysis carried out in this study, edible bean-IT07K-243-1-10 among others appears to have the greatest quantity of mineral elements followed by edible bean-IT04K-333-2 and wild bean-feregede. Edible bean-IT97K-499-35 has the least mineral content compared to other bean samples followed closely is the wild bean-Otili with least mineral content. Wild and near extinct bean feregede is recommended for human consumption because it contains appreciable amount of minerals and antioxidants compare to other cultivated edible beans.

\section{Acknowledgements}

The present project was partly funded by Tet Fund Research Grant 2015.

\section{References}

[1] Earle, O.L. (1971) Peas, Beans, and Licorice. William Morrow and Company, New York.

[2] De Mejia, E., Guzman-Maldonado, S.H., Acosta-Gallegos, J.A., Reynoso-Camacho, R., Ramirez-Rodriguez, E., PonsHernandez, J.L., Gonzalez-Chavira, M.M., Castellanos, J.Z. and Nelly, J.D. (2003) Effect of Cultivar and Growing Location on the Trypsin Inhibitors, Tannins and Lectins of Common Beans (Phaseolus vulgaris L.) Grown in Semiarid Highlands of Mexico. Journal of Agricultural and Food Chemistry, 51, 5962-5966. http://dx.doi.org/10.1021/jf030046m

[3] Duke, L. (1981) Handbook of Legumes of World Economic Importance. Plenum Press, New York, 170-184. http://dx.doi.org/10.1007/978-1-4684-8151-8

[4] Weaver, W. (2003) Peas. In: Katz, S.H., Ed., Vols. 1-3, Encyclopedia of Food and Culture, Charles Scribner \& Sons, 
New York.

[5] Tobias, R. (2004) Beans. The Oxford Encyclopedia of Food and Drink in America. 2nd Edition, Oxford University Press.

[6] McDonald, M.B. (1998) Seed Quality Assessment. Seed Science Research, 8, 265-275. http://dx.doi.org/10.1017/S0960258500004165

[7] Mitchell, D.C., Lawrence, F.R., Hartman, T.J. and Curran, J.M. (2009) Consumption of Dry Beans, Peas, and Lentils Could Improve Diet Quality in the US Population. Journal of the American Dietetic Association, 109, 909-913. http://dx.doi.org/10.1016/j.jada.2009.02.029

[8] Hughes, J.S., Ganthavorn, C. and Wilson-Sanders, S. (1997) Dry Beans Inhibit Azoxymethane-Induced Colon Carcinogenesis in F344 Rats. Journal of Nutrition, 127, 2328-2333.

[9] Hangen, L. and Bennink, M.R. (2002) Consumption of Black and Navy Beans Phaseolus vulgaris Reduced Azoxymethane-Induced Colon Cancer in Rats. Nutrition and Cancer, 40, 60-65.

[10] Oseguera-Toledo, M.E., de Mejia, E.G., Dia, V.P. and Amaya-Llano, S.L. (2011) Common Bean (Phaseolus vulgaris L.) Hydrolysates Inhibit Inflammation in LPS-Induced Macrophages through Suppression of NF- $\kappa$ B Pathways. Food Chemistry, 127, 1175-1185. http://dx.doi.org/10.1016/j.foodchem.2011.01.121

[11] Hansen, R.D., et al. (2013) Effects of Antioxidant Micronutrients on Risk of Colorectal Cancer. Clinical Gastroenterology and Hepatology, 11, 406-415. http://dx.doi.org/10.1016/j.cgh.2012.10.039

[12] Abbey, B.W. and Ibeh, G.O. (1987) Functional Properties of Raw and Heat Processed Brown Bean (Canavalia rosea DC) Flour. Journal of Food Science, 52, 406-408. http://dx.doi.org/10.1111/j.1365-2621.1987.tb06625.X

[13] Ahenkora, K., Dadzie, M. and Osei-Bonsu, P. (1999) Composition and Functional Properties of Raw and Heat Processed Velvet Bean (Mucuna pruriens (L.) DC. var. Utilis) Flours. International Journal of Food Science \& Technology, 34, 131-135. http://dx.doi.org/10.1046/j.1365-2621.1999.00244.x

[14] Agbede, J.O. and Aletor, V.A. (2005) Studies of the Chemical Composition and Protein Quality Evaluation of Differently Processed Canavalia ensiformis and Mucuna pruriens Seed Flours. Journal of Food Composition and Analysis, 18, 89-103. http://dx.doi.org/10.1016/j.jfca.2003.10.011

[15] Balogun, A.M. and Fetuga, B.L. (1986) Chemical Composition of Some Underexploited Leguminous Crop Seeds in Nigeria. Journal of Agricultural and Food Chemistry, 34, 189-192. http://dx.doi.org/10.1021/jf00068a008

[16] Ajayi, I.A., Oderinde, R.A., Kajogbola, D.O. and Ukponi, J.U. (2006) Oil Content and Fatty Acid Composition of Some Underutilized Legumes from Nigeria. Food Chemistry, 99, 115-120. http://dx.doi.org/10.1016/j.foodchem.2005.06.045

[17] Fasoyiro, S., Ajibade, S.R., Omole, A.J., Adeniyan, O.N. and Farinde, E.O. (2006) Proximate, Minerals and Antinutritional Factors of Some Underutilized Grain Legumes in South-Western Nigeria. Nutrition and Food Science, 36, 1823. http://dx.doi.org/10.1108/00346650610642151

[18] Nwosu, J.N. (2013) Evaluation of the Proximate Composition and Antinutritional Properties of African Yam Bean (Sphenostylis sternocarpa) Using Malting Treatment. International Journal of Basic and Applied Sciences, 2, 157-169.

[19] Maciej, R. and Krzysztof, G. (2007) Modification of Spectrometric Methods for Antioxidative Vitamins Determination Convenient in Analytic Practice. Acta Scientiarum Polonorum/Technologia Alimentaria, 6, 17-28.

[20] Benderitter, M., Maupoil, V., Vergely, C., Dalloz, F., Briot, F. and Rochette, L. (1998) Studies by Electron Paramagnetic Resonance of the Importance of Iron in the Hydroxyl Scavenging Properties of Ascorbic Acid in Plasma: Effects of Iron Chelators. Fundamental \& Clinical Pharmacology, 12, 510-516. http://dx.doi.org/10.1111/j.1472-8206.1998.tb00979.x

[21] Garcia, E.J., Oldoni, T.L.C., Alencar, S.M., Reis, A., Loguercio, A.D. and Grande, R.H.M. (2012) Antioxidant Activity by DPPH Assay of Potential Solutions to Be Applied on Bleached Teeth. Brazilian Dental Journal, 23, 22-27. http://dx.doi.org/10.1590/S0103-64402012000100004

[22] Winham, D., Webb, D. and Barr, A. (2008) Beans and Good Health. Nutrition Today, 43, 201-209. http://dx.doi.org/10.1097/01.NT.0000303354.21347.45

[23] Anderson, J.W., Gustafson, N.J., Spencer, D.B., Tietyen, J. and Bryant, C.A. (1990) Serum Lipid Response of Hypercholesterolemic Men to Single and Divided Doses of Canned Beans. The American Journal of Clinical Nutrition, 51, 1013-1019.

[24] Winham, D.M., Hutchins, A.M. and Johnston, C.S. (2007) Pinto Bean Consumption Reduces Biomarkers for Heart Disease Risk. Journal of the American College of Nutrition, 26, 243-249. http://dx.doi.org/10.1080/07315724.2007.10719607

[25] Geil, P.B. and Anderson, J.W. (1994) Nutrition and Health Implications of Dry Beans: A Review. Journal of the American College of Nutrition, 13, 549-558. http://dx.doi.org/10.1080/07315724.1994.10718446 
[26] Xu, B. and Chang, S.K. (2009) Total Phenolic, Phenolic Acid Anthocyanin, Flavan-3-ol and Flavonol Profiles and Antioxidant Properties of Pinto and Black Beans (Phaseolus vulgaris L) as Affected by Thermal Processing. Journal of Agricultural and Food Chemistry, 57, 4754-4764. http://dx.doi.org/10.1021/jf900695s

[27] Cardador-Martínez, A., Castaño-Tostado, E. and Loarca-Piña, G. (2002) Antimutagenic Activity of Natural Phenolic Compounds in the Common Bean (Phaseolus vulgaris) against Aflatoxin $\mathrm{B}_{1}$. Food Additives \& Contaminants, 19, 62-69. http://dx.doi.org/10.1080/02652030110062110

[28] Aparicio-Fernández, X., Manzo-Bonilla, L. and Loarca-Piña, G.F. (2005) Comparison of Antimutagenic Activity of Phenolic Compounds in Newly Harvested and Stored Common Beans Phaseolus vulgaris against Aflatoxin $\mathrm{B}_{1}$. Journal of Food Science, 70, S73-S78. http://dx.doi.org/10.1111/j.1365-2621.2005.tb09068.x

[29] Oomah, B.D., Corbé, A. and Balasubramanian, P. (2010) Antioxidant and Anti-Inflammatory Activities of Bean (Phaseolus vulgaris L.) Hulls. Journal of Agricultural and Food Chemistry, 58, 8225-8230. http://dx.doi.org/10.1021/jf1011193

[30] Del Rio, D., Rodriguez-Mateos, A., Spencer, J.P.E., Tognolini, M., Borges, G. and Crozier, A. (2012) Dietary Polyphenolics in Human Health: Structures, Bioavailability, and Evidence of Protective Effects against Chronic Diseases. Antioxidants \& Redox Signaling, 12, 5-6.

[31] Finley, J.W., Burrell, J.B. and Reeves, P.G. (2007) Pinto Bean Consumption Changes SCFA Profiles in Fecal Fermentations, Bacterial Populations of the Lower Bowel and Lipid Profiles of Human. Journal of Nutrition, 137, 2391-2398.

[32] Dahl, L.K. (1972) Salt and Hypertension. American Journal of Clinical Nutrition, 25, 231-238.

[33] Onibon, V.O., Abulude, F.O. and Lawal, L. (2007) Nutritional and Anti-Nutritional Composition of Some Nigeria Beans. Journal of Food Technology, 5, 120-122.

[34] Lucier, G., Lin, B.H., Allshouse, J. and Kantor, L.S. (2000) Factor Affecting Dry Bean Consumption in the United States. Economic Research Service, VGS-280, 26-34.

[35] Campos-Vega, R., Reynoso-Camacho, R., Pedraza-Aboytes, G., Acosta-Gallegos, J.A., Guzman-Maldonado, S.H., Paredes-Lopez, O., Oomah, B.D. and Loarca-Piña, G. (2009) Chemical Composition and in Vitro Polysaccharide Fermentation of Different Beans (Phaseolus vulgaris L.). Journal of Food Science, 74, T59-T65. http://dx.doi.org/10.1111/j.1750-3841.2009.01292.x

[36] Tako, E., Glahn, R.P., Laparra, J.M., Welch, R.M., Lei, X., Kelly, J.D., Rutzke, M.A. and Miller, D.D. (2009) Iron and Zinc Bioavailabilities to Pigs from Red and White Beans (Phaseolus vulgaris L.) Are Similar. Journal of Agricultural and Food Chemistry, 57, 3134-3140. http://dx.doi.org/10.1021/jf803647m

[37] Nestel, P., Bouis, H.E., Meenaksh, J.V. and Pfeiffer, W. (2006) Bio-Fortification of Staple Food Crops. Journal of Nutrition, 136, 1064-1067.

[38] Carlson, D., Norgarr, J.V., Toroun, B., Cakmak, I. and Poulson, H.D. (2012) Bioavailability of Trace Elements in Beans and Zinc-Biofortified Wheat in Pigs. Biological Trace Element Research, 150, 147-153. http://dx.doi.org/10.1007/s12011-012-9453-2

[39] Arinathan, V., Mohan, V.R., De-Britto, A.J. and Chelladurai, V. (2003) Studies on Food and Medicinal Plants of Western Ghats. Journal of Economic and Taxonomic Botany, 27, 750-753.

[40] Arun, A.B., Sridhar, K.R., Raviraja, N.S., Schmidt, E. and Jung, K. (2003) Nutritional and Antintritional Components of Canavalia spp. Seeds from the West Coast Sand Dunes of India. Plant Foods for Human Nutrition, 58, 1-13. http://dx.doi.org/10.1023/B:QUAL.0000040340.86158.61

[41] Aletor, V.A. and Aladetimi, O.O. (1989) Compositional Evaluation of Some Cowpea Varieties and Some Under-Utilised Edible Legumes in Nigeria. Die Nahrung, 33, 999-1007. http://dx.doi.org/10.1002/food.19890331023

[42] Oboh, G. and Akindahunsi, A.A. (2004) Change in the Ascorbic Acid, Total Phenol and Antioxidant Activity of Some Sun-Dried Green Leafy Vegetables in Nigeria. Nutrition and Health, 18, 29-36. http://dx.doi.org/10.1177/026010600401800103 